\title{
Factors Influencing Behavioural Intention to Use Mobile Banking in Champawat District of Uttrakhand
}

\author{
Anil Mehta, Deepankar Chakrabarti, Rajeev Srivastava, Ranjeet Mehta
}

\begin{abstract}
India has more mobile connections compared to banking accounts, therefore GoI in Economic Survey 2014-15, proposed JAM (Jan-Dhan Yojana, Aadhar Number and Mobile Number) trinity to use ICT for more efficient and effective spread of formal banking even to the hilly areas where brick and mortar banks are challenging to build and sustain. Also, financial inclusion cannot happen without economic activity, and Mahatma Gandhi National Rural Employment Act (MGNREGA) is a policy which significantly helped to enhance the economic activity of rural India. Because of penetration of mobile technology and involvement of the same in financial inclusion, this research will contribute to understanding the constructs of mobile banking adoption in hilly rural area of Champawat District, Uttrakhand w.r.t population registered with MGNREGA. The authors found research is scarce for mobile banking adoption in hilly rural areas of India. (Mehta et, al 2019) may be the only study for Champawat district of Uttrakhand, using technology acceptance model (TAM) and total interpretive structural modelling (TISM) to develop a model. This paper takes model from Mehta et al. 2019 and examines the relationship between the constructs using structured equation modelling (SEM).
\end{abstract}

Keywords: Financial Inclusion, Mobile Banking, Technology Acceptance Model (TAM), Intention Behavior, Hilly Rural India, Total Interpretive Structural Modeling (TISM), Structured Equation Modeling(SEM)

\section{INTRODUCTION}

Due to increased competition in the banking sector, banks were encouraged to adopt new technologies (Alalwan et al., 2017; Koksal, 2016). The new digital distribution platform is mobile banking. As the Internet has developed into a mobile phone, mobile phones are used to carry out banking transactions (Koenig-Lewis et al. 2010). With the advent of mobile banking, banks have become more effective in reducing operating cost and time, while offering customers considerable convenience and enabling them to conduct banking. Based on the variables contained in the literature study by (Mehta et al. 2019) and the outcome of which the model was based on the TAM and TISM, the author intends to broaden the below-shown model and add to the literature on influencers for mobile banking use in hilly area of Champawat district, Uttrakhand.

\section{Revised Manuscript Received on December 30, 2019.}

* Correspondence Author

Mehta - Research Scholar, University Of Petroleum And Energy Studies, Dehradun, India

Dr. Deepankar Chakrabarti - Professor And Dean, University Of Petroleum And Energy Studies, Dehradun, India

Dr. Rajeev Srivastava - Head Of Department, Decision Science Department, University Of Petroleum And Energy Studies, Dehradun, India Dr. Ranjeet Mehta - Principal Director, PHD Chambers, New Delhi, India

(c) The Authors. Published by Blue Eyes Intelligence Engineering and Sciences Publication (BEIESP). This is an open access article under the CC BY-NC-ND license (http://creativecommons.org/licenses/by-nc-nd/4.0/)

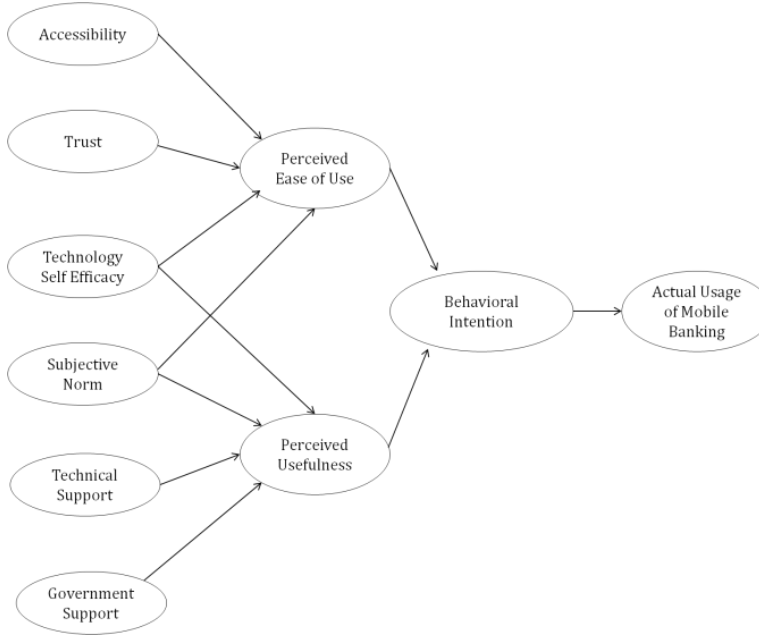

Figure 1: Conceptual Model

As shown in Figure 1, (Mehta et al. 2019) suggested the conceptual model using TISM by taking extended TAM as a base model. This study will test the same model by using SEM

\section{FORMULATION OF HYPOTHESIS}

From the conceptual model, two hypotheses and these were tested using Structured Equation Modeling

H1 - There is no relationship between Perceived Ease of Use and Behavioral Intention towards the usage of Mobile Banking in hilly rural India

H2 - There is no relationship between Perceived Usefulness and Behavioral Intention towards the usage of Mobile Banking in hilly rural India

\section{DATA MINING}

The data collected from 425 respondents from various villages under the district of Champawat. The degree of response checked after collecting data from the field to figure out the efficiency of the questionnaire design and method of collecting data. Twenty-two entries showed irregularities, and therefore, 403 considered out of 425 entries for data analysis. Out of these 22 entries, 13 entries were from respondents who were not able to show the MNREGA job card and, other respondents from the other nine entries marked all extremes. These twenty-two entries were random across the blocks. The summary of the removed entries has shown in Figure 2 below.

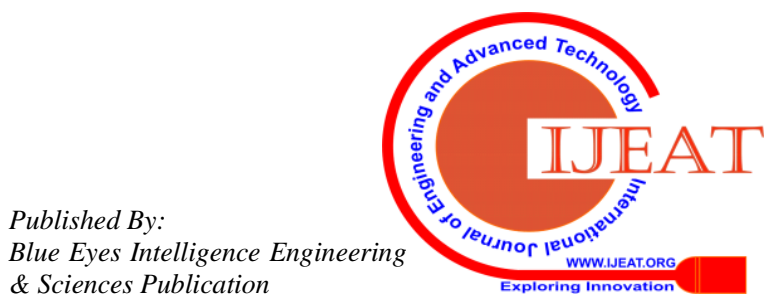




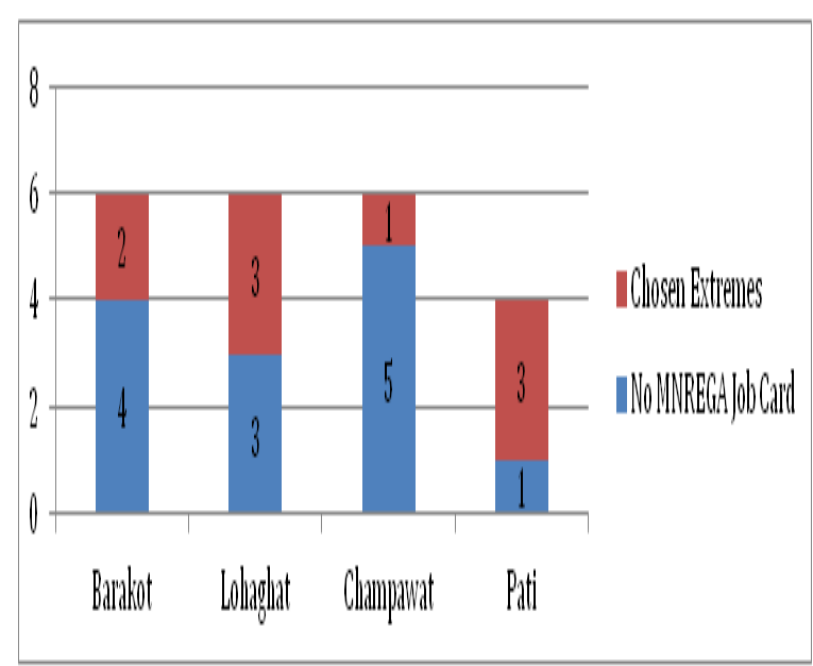

Figure 2: Removed Entries

A careful administration for non-response bias is required while dealing with questionnaires and, this carefulness increases when the circulation of questionnaires is in a rural setup. This paper caters the non-bias response for the four demographic variables, namely; age, level of education, monthly income and occupation. The comparison between the two groups of respondents was made using ANOVA. The first group was of 40 respondents who filled genuine entries and 40 respondents whose missing entries filled manually. Table 1 shows the response bias analysis:

Table 1 - Response Bias Analysis

\begin{tabular}{|l|c|c|}
\hline Demographic Entry & \multicolumn{2}{|c|}{ Results of ANOVA (First 40 vs. Last 40) } \\
\hline & F Value & Level of Significance \\
\hline Age & 0.786 & 0.576 \\
\hline Level of Education & 0.846 & 0.505 \\
\hline Monthly Income & 1.134 & 0.457 \\
\hline Occupation & 0.576 & 0.698 \\
\hline
\end{tabular}

This analysis indicates that there is no response bias and also the entries that entered instead of missing entries were done carefully.

Paper manages missing data and also applies the Malhanobis test. This test reveals a maximum of $0.8 \%$ of data was missing for each construct item, and randomness of missing entries was also insignificant, as shown in Table 2:

Table 2 - Chi-Square Test

\begin{tabular}{|c|c|c|}
\hline $\mathrm{X}^{2}$ & Degrees of Freedom & Sig. \\
\hline $\mathbf{8 4 9 . 3 3 8}$ & 878 & 0.75 \\
\hline
\end{tabular}

The missing data values will be replaced using the two-step procedure of "Regression Imputation" (Allison, 2003; Frane, 1976).

\section{DEMOGRAPHIC SUMMARY OF RESPONDENT'S CHARACTERISTICS}

It is also important to understand the distribution of nominal and categorical data, which, will help to explain the dynamics of respondents. There was an equal distribution of questionnaires across 70 villages out of 662 inhabited villages in 4 blocks of Champawat. A total of 717 villages are under the district. The respondents were using mobile banking under MGNREGA.

The ratio of male to female respondents was 3 to 2, i.e., $65 \%$ male and $35 \%$ female, which is the same as MGNREGA policy which mentions $1 / 3^{\text {rd }}$ of the employment should be given to female population.

The distribution of the age of the respondents clearly shows that the respondents enrolled for MGNREGA are either between 18 -38 years of age (74.4\%) or above 58 years of age (15.4\%). Table 3 below shows the distribution.

Table 3 - Age-wise distribution of respondents

\begin{tabular}{|l|l|c|}
\hline S.No & $\begin{array}{c}\text { Age } \\
\text { Group }\end{array}$ & $\begin{array}{c}\text { Total } \\
\text { Entries }\end{array}$ \\
\hline 1. & $18-28$ & 202 \\
\hline 2. & $28-38$ & 98 \\
\hline 3. & $38-48$ & 17 \\
\hline 4. & $48-58$ & 24 \\
\hline 5. & $\begin{array}{l}\text { Above } 58 \\
\text { years }\end{array}$ & 62 \\
\hline
\end{tabular}

The data also shows that the majority of respondents were divided among illiterate or functional literate, while very few were graduates. Table 4 shows the respondent data:

Table 4 - Education-wise distribution of respondents

\begin{tabular}{|l|l|c|}
\hline S.No & Education & Total Entries \\
\hline 1. & Illiterate & 103 \\
\hline 2. & $\begin{array}{l}\text { Functional } \\
\text { Literate }\end{array}$ & 154 \\
\hline 3. & Primary & 44 \\
\hline 4. & $\begin{array}{l}\text { Upper } \\
\text { Primary }\end{array}$ & 34 \\
\hline 5. & High School & 30 \\
\hline 6. & Intermediate & 29 \\
\hline 7. & Graduate & 13 \\
\hline
\end{tabular}

The results show that $75 \%$ of the respondents were between 18-38 years of age. Hence, the younger generation uses mobile banking, and also literacy rate doesn't affect the use of mobile banking.

\section{EXPLORATORY FACTOR ANALYSIS (EFA)}

EFA will be used to find relationships between Perceived Ease of Use, Perceived Usefulness, Behavior Intention, and usage of mobile banking in hilly rural India. This research paper uses principal component analysis (PCA) and utilises the orthogonal framework with a varimax rotation technique to perform factor analysis.

The EFA results checked and verified using confirmatory factor analysis (CFA) using structural equation modelling (SEM). The first step is to check the acceptance of sample adequacy in the research, for this Kaiser-Meyer-Olkin (KMO) and Bartlett's test of sphericity was employed. The test clearly showed that factor analysis could be done using sample data. KMO measure of sampling came out to be 0.913. Also, Bartlett's test revealed approx chi-square was 11456.62, Degrees of Freedom was 832 and Sig. (p-value) $<0.001$. Next is to check the communalities for the variables, and if the communality is less than $50 \%$, it leads to the exclusion of the variable from the analysis. The analysis revealed that communalities of all the variables loaded on EFA varied from 0.630 to 0.904 with average communality of 0.808 , which makes the model highly acceptable model. The method of extraction was Principal Component Analysis. EFA, based on the common factor model, was used to understand the relationship between a large set of variables.

Published By:

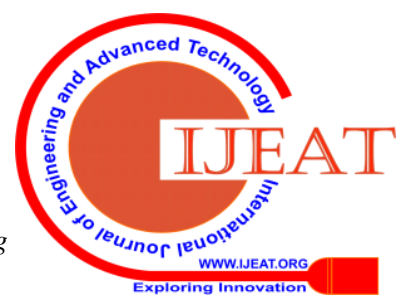


Table 5 below shows the total number of factors extracted and total variance explained in EFA model.

Table 5 - EFA Model - Factors Extracted and Total Variance

\begin{tabular}{|l|l|l|l|l|l|l|l|l|l|}
\hline Items & \multicolumn{2}{|l|}{ Initial Eigen Value } & \multicolumn{5}{|l|}{$\begin{array}{l}\text { Extraction Sums of Square } \\
\text { Loading }\end{array}$} & \multicolumn{3}{|l|}{$\begin{array}{l}\text { Rotation Sums of Squared } \\
\text { Loadings }\end{array}$} \\
\hline & $\begin{array}{l}\text { Cumulativ } \\
\text { e } \%\end{array}$ & $\begin{array}{l}\% \text { of } \\
\text { Variance }\end{array}$ & Total & $\begin{array}{l}\text { Cumulativ } \\
\text { e } \%\end{array}$ & $\begin{array}{l}\text { \% of } \\
\text { Variance }\end{array}$ & Total & $\begin{array}{l}\text { lumulativ } \\
\text { e } \%\end{array}$ & $\begin{array}{l}\% \text { of } \\
\text { Variance }\end{array}$ & Total \\
\hline AU & 38.308 & 38.308 & 14.17 & 38.308 & 38.308 & 14.17 & 17.022 & 17.022 & 6.3 \\
\hline BI & 48.16 & 9.852 & 3.645 & 48.16 & 9.852 & 3.645 & 30.094 & 13.071 & 4.84 \\
\hline PU & 54.634 & 6.475 & 2.396 & 54.634 & 6.475 & 2.396 & 41.034 & 10.94 & 4.05 \\
\hline PEoU & 61.02 & 6.386 & 2.363 & 61.02 & 6.386 & 2.363 & 51.416 & 10.382 & 3.84 \\
\hline SN & 66.185 & 5.165 & 1.911 & 66.185 & 5.165 & 1.911 & 61.773 & 10.357 & 3.83 \\
\hline TR & 70.466 & 4.28 & 1.584 & 70.466 & 4.28 & 1.584 & 66.595 & 4.822 & 1.78 \\
\hline TSE & 74.29 & 3.824 & 1.415 & 74.29 & 3.824 & 1.415 & 71.399 & 4.804 & 1.78 \\
\hline AC & 78.089 & 3.799 & 1.406 & 78.089 & 3.799 & 1.406 & 76.176 & 4.776 & 1.77 \\
\hline GS & 80.899 & 2.81 & 1.04 & 80.899 & 2.81 & 1.04 & 80.899 & 4.724 & 1.75 \\
\hline TS & 82.278 & 1.379 & 0.51 & & & & & & \\
\hline
\end{tabular}

Table 6 shows the data of the rotated component matrix, which corresponds to the loading of measured items on latent factors. Here Principal Component Analysis has been used as an extraction method, Varimax with Kaiser Normalization was used for rotation method with rotation converged in 6 iterations. All nine latest factors contribute to the actual usage of mobile banking. It was observed that 0.30 is the minimum criteria between the constructs and therefore justified the factor loading.

Table 6 - Rotated Component Matrix

\begin{tabular}{|c|c|c|c|c|c|c|c|c|c|}
\hline Components & 1 & 2 & 3 & 4 & 5 & 6 & 7 & 8 & 9 \\
\hline Accessibility & 0.123 & 0.842 & 0.132 & 0.127 & 0.136 & 0.113 & 0.136 & 0.035 & 0.035 \\
\hline Clear & 0.102 & 0.874 & 0.072 & 0.112 & 0.082 & 0.09 & 0.051 & 0.005 & 0.025 \\
\hline Comfort in reference manual & 0.224 & 0.153 & 0.106 & 0.212 & 0.78 & 0.052 & 0.113 & 0.082 & 0.022 \\
\hline Comfort in using first time & 0.165 & 0.213 & 0.194 & 0.162 & 0.767 & 0.062 & 0.043 & 0.092 & 0.092 \\
\hline Comfort learning from peers & 0.165 & 0.079 & 0.134 & 0.167 & 0.827 & 0.082 & 0.016 & 0.103 & 0.045 \\
\hline Comfort learning on my own & 0.235 & 0.045 & 0.112 & 0.023 & 0.846 & 0.113 & 0.098 & 0.067 & 0.043 \\
\hline Consistency & 0.242 & 0.172 & 0.249 & 0.806 & 0.115 & 0.036 & 0.098 & 0.023 & 0.082 \\
\hline Consistency & 0.164 & 0.136 & 0.125 & 0.124 & 0.183 & 0.167 & 0.034 & 0.864 & -0.03 \\
\hline Continuity & 0.234 & 0.195 & 0.297 & 0.758 & 0.149 & 0.103 & 0.067 & 0.087 & 0.086 \\
\hline Ease and Variety of Access & 0.152 & 0.176 & 0.124 & 0.083 & 0.066 & 0.547 & 0.043 & 0.004 & 0.904 \\
\hline Easier Transaction & 0.241 & 0.039 & 0.775 & 0.245 & 0.135 & 0.045 & 0.049 & 0.124 & 0.092 \\
\hline Easy to learn & 0.09 & 0.814 & 0.173 & 0.145 & 0.183 & 0.074 & 0.046 & 0.12 & 0.095 \\
\hline Flexibility & 0.065 & 0.789 & -0.029 & 0.164 & 0.083 & 0.048 & -0.066 & -0.009 & 0.034 \\
\hline Fraud Free & 0.121 & 0.035 & 0.032 & 0.126 & 0.136 & -0.021 & 0.914 & 0.054 & 0.053 \\
\hline Future Use & 0.225 & 0.226 & 0.241 & 0.746 & 0.219 & 0.141 & 0.134 & 0.045 & 0.036 \\
\hline Government Facilitation & 0.134 & 0.152 & 0.114 & 0.147 & 0.072 & 0.887 & -0.004 & 0.152 & 0.073 \\
\hline Improved Effectiveness & 0.242 & 0.106 & 0.834 & 0.136 & 0.112 & 0.075 & 0.04 & 0.043 & 0.021 \\
\hline Improved Productivity & 0.236 & 0.102 & 0.816 & 0.202 & 0.172 & 0.036 & 0.07 & 0.025 & 0.123 \\
\hline Influence of Family & 0.765 & 0.114 & 0.215 & 0.114 & 0.049 & -0.006 & -0.021 & 0.197 & 0.135 \\
\hline Influence of friends & 0.843 & 0.103 & 0.112 & 0.101 & 0.187 & 0.132 & 0.033 & 0.07 & 0.037 \\
\hline Influence of Media & 0.787 & 0.123 & 0.189 & 0.2 & 0.156 & 0.032 & 0.024 & 0.024 & 0.035 \\
\hline Often and Diverse Use & 0.269 & 0.224 & 0.236 & 0.782 & 0.235 & 0.112 & 0.042 & 0.041 & 0.074 \\
\hline Overall Comfort in usage & 0.164 & 0.203 & 0.157 & 0.124 & 0.809 & 0.032 & 0.103 & 0.103 & 0.034 \\
\hline Overall Rating & 0.143 & 0.834 & 0.104 & 0.148 & 0.162 & 0.053 & 0.102 & 0.136 & 0.136 \\
\hline Overall rating & 0.824 & 0.111 & 0.146 & 0.185 & 0.112 & 0.145 & 0.083 & 0.012 & 0.071 \\
\hline Peer Influence & 0.782 & 0.023 & 0.183 & 0.175 & 0.178 & 0.03 & 0.068 & 0.012 & 0.087 \\
\hline Quick & 0.169 & 0.116 & 0.11 & 0.101 & 0.168 & 0.115 & 0.013 & 0.888 & -0.035 \\
\hline Quick Transaction & 0.293 & 0.118 & 0.786 & 0.236 & 0.184 & 0.074 & 0.096 & 0.064 & -0.012 \\
\hline Recommendations to Peers & 0.236 & 0.236 & 0.234 & 0.813 & 0.123 & 0.096 & 0.078 & 0.103 & 0.016 \\
\hline Saves Time & 0.248 & 0.054 & 0.811 & 0.206 & 0.136 & 0.052 & 0.063 & 0.087 & 0.118 \\
\hline Security of Money & 0.076 & 0.126 & 0.121 & 0.08 & 0.154 & 0.003 & 0.872 & 0.021 & 0.66 \\
\hline Sharing Experience & 0.836 & 0.084 & 0.134 & 0.112 & 0.165 & 0.102 & 0.031 & 0.042 & 0.061 \\
\hline Skill Improvement & 0.152 & 0.825 & 0.083 & 0.186 & 0.152 & 0.14 & 0.036 & 0.041 & 0.054 \\
\hline Societal Influence & 0.772 & 0.134 & 0.198 & 0.136 & 0.121 & 0.025 & 0.054 & 0.126 & 0.09 \\
\hline Teaching others & 0.811 & 0.078 & 0.176 & 0.198 & 0.135 & 0.05 & 0.07 & 0.035 & 0.065 \\
\hline Technology Promotion & 0.131 & 0.185 & 0.142 & 0.151 & 0.132 & 0.873 & -0.021 & 0.13 & 0.034 \\
\hline Unrestricted Access & 0.162 & 0.146 & 0.113 & 0.036 & 0.067 & 0.025 & 0.056 & -0.043 & 0.914 \\
\hline
\end{tabular}

EFA provided nine latent factors, which were the result of the sum of rating scores of all loaded items on each factor. The reliability and cross reliability of each variable and each question respectively were checked to develop a strong framework. Table 7 shows reliability statistics, and Table 8 shows total statistics. Total statistics of each construct revealed that if any item as shown in Table 8 of any of the construct will be deleted, then the Cronbach's Alpha of the corresponding construct can't be increased.
Table 7 - Reliability Statistics of the nine constructs:

\begin{tabular}{|l|l|l|l|l|}
\hline S.No & Construct & $\begin{array}{l}\text { Cronbach' } \\
\text { S Alpha }\end{array}$ & $\begin{array}{l}\text { Cronbach's Alpha } \\
\text { Based on } \\
\text { Standardized } \\
\text { Items }\end{array}$ & $\begin{array}{l}\text { No. of } \\
\text { Items }\end{array}$ \\
\hline 1. & PU & 0.937 & 0.937 & 5 \\
\hline 2. & PEoU & 0.923 & 0.923 & 6 \\
\hline 3. & SN & 0.937 & 0.937 & 8 \\
\hline 4. & TSE & 0.915 & 0.916 & 5 \\
\hline 5. & AC & 0.864 & 0.864 & 2 \\
\hline 6. & TR & 0.871 & 0.871 & 2 \\
\hline 7. & GS & 0.892 & 0.892 & 2 \\
\hline 8. & TSE & 0.888 & 0.889 & 2 \\
\hline 9. & BI & 0.944 & 0.944 & 5 \\
\hline
\end{tabular}

The results from Table 7 and Table 8 signifies that variables can derive the latent factors, and also reliability of the variables points out that basic TAM variables Perceived usefulness, Perceived Ease of Use and Behavioral Intention could be used to study mobile banking usage.

Table 8 - Total Statistics of constructs

\begin{tabular}{|c|c|c|c|c|c|c|}
\hline Constructs & Items & $\begin{array}{c}\text { Cronbach } \\
\text { Alpha of } \\
\text { item } \\
\text { deleted }\end{array}$ & \begin{tabular}{|c|} 
Squared \\
multiple \\
correlation
\end{tabular} & \begin{tabular}{|c|} 
Corrected \\
Inter-item \\
correlation
\end{tabular} & $\begin{array}{c}\text { Scale } \\
\text { variance if } \\
\text { item } \\
\text { delted }\end{array}$ & \begin{tabular}{|c|} 
Scale \\
Mean if \\
item \\
deleted
\end{tabular} \\
\hline \multirow[t]{5}{*}{ PU } & Easier Transaction & 0.915 & 0.697 & 0.842 & 45.403 & 18.68 \\
\hline & Improved Effectiveness & 0.931 & 0.736 & 0.862 & 24.883 & 18.82 \\
\hline & Improved Productivity & 0.913 & 0.643 & 0.821 & 45.092 & 18.69 \\
\hline & Saves time & 0.922 & 0.714 & 0.827 & 46.115 & 18.87 \\
\hline & Quick Transaction & 0.924 & 0.725 & 0.841 & 44.784 & 18.85 \\
\hline \multirow[t]{6}{*}{ PEoU } & Skill Improvement & 0.911 & 0.765 & 0.812 & 66.711 & 23.8 \\
\hline & Clear & 0.915 & 0.645 & 0.813 & 65.545 & 23.76 \\
\hline & Flexible & 0.939 & 0.465 & 0.696 & 69.032 & 24.13 \\
\hline & Easy to Learn & 0.922 & 0.723 & 0.823 & 66.523 & 23.76 \\
\hline & Accessibility & 0.919 & 0.745 & 0.865 & 66.923 & 23.83 \\
\hline & Overall Rating & 0.915 & 0.721 & 0.864 & 65.765 & 23.86 \\
\hline \multirow[t]{8}{*}{$\mathrm{SN}$} & Teaching others & 0.942 & 0.715 & 0.864 & 124.834 & 32.82 \\
\hline & Influence of friends & 0.945 & 0.724 & 0.813 & 125.834 & 32.7 \\
\hline & Societal Influence & 0.956 & 0.665 & 0.834 & 128.556 & 32.62 \\
\hline & Influence of family & 0.923 & 0.656 & 0.745 & 128.122 & 32.65 \\
\hline & Sharing Experience & 0.951 & 0.716 & 0.813 & 125.452 & 32.76 \\
\hline & Peer Influence & 0.955 & 0.683 & 0.834 & 128.603 & 32.76 \\
\hline & Influence of Media & 0.946 & 0.715 & 0.832 & 125.932 & 32.79 \\
\hline & Overall Rating & 0.943 & 0.734 & 0.845 & 126.363 & 32.75 \\
\hline \multirow[t]{5}{*}{ TSE } & Comfort learning on my own & 0.897 & 0.628 & 0.78 & 39.537 & 19.16 \\
\hline & Comfort Learning from Peers & 0.896 & 0.623 & 0.784 & 38.531 & 19.18 \\
\hline & Comfort in using first time & 0.904 & 0.573 & 0.747 & 39.29 & 19.05 \\
\hline & \begin{tabular}{|llr}
$\begin{array}{l}\text { Comfort } \\
\text { manual }\end{array}$ & with reference \\
\end{tabular} & 0.894 & 0.643 & 0.797 & 37.926 & 19.08 \\
\hline & Overall comfort in usage & 0.891 & 0.662 & 0.81 & 38.558 & 19.19 \\
\hline \multirow[t]{2}{*}{$A C$} & Ease and variety of access & (a) & 0.58 & 0.761 & 3.963 & 4.62 \\
\hline & Unrestricted access & .(a) & 0.58 & 0.761 & 3.845 & 4.55 \\
\hline \multirow[t]{2}{*}{ TR } & Security of money & (a) & 0.596 & 0.772 & 3.68 & 4.62 \\
\hline & Fraud Free & .(a) & 0.596 & 0.772 & 3.779 & 4.69 \\
\hline \multirow[t]{2}{*}{ GS } & Technology Promotion & (a) & 0.647 & 0.805 & 3.825 & 4.42 \\
\hline & Government Facilitation & .(a) & 0.647 & 0.805 & 3.625 & 4.47 \\
\hline \multirow[t]{2}{*}{ TSE } & Network Availability & (a) & 0.64 & 0.8 & 3.675 & 4.7 \\
\hline & Customer Care & .(a) & 0.64 & 0.8 & 3.307 & 4.76 \\
\hline \multirow[t]{5}{*}{$\mathrm{Bl}$} & Recommendation to Peers & 0.927 & 0.732 & 0.871 & 45.373 & 19.43 \\
\hline & Continuity & 0.934 & 0.732 & 0.864 & 44.703 & 19.63 \\
\hline & Often and Diverge Usage & 0.932 & 0.751 & 0.862 & 44.532 & 19.74 \\
\hline & Future Usage & 0.927 & 0.711 & 0.824 & 45.894 & 19.71 \\
\hline & Consistency & 0.932 & 0.742 & 0.852 & 43.799 & 19.85 \\
\hline
\end{tabular}

The next aim is to derive the latent factors and relationship between the variables which would be useful for taking care of transitivity. The Bivariate Pearson's correlation significant at 0.01 levels (**2-tailed) has been used to check the linearity of the test in the data. Table 9 shows that government support and technical support shows a negative correlation. 
Factors Influencing Behavioural Intention to Use Mobile Banking in Champawat District of Uttrakhand

Table 9 - Pearsons' Bivariate Correlations between latent constructs

\begin{tabular}{|c|c|c|c|c|c|c|c|c|c|}
\hline & PU & PEoU & $\mathrm{SN}$ & TSE & $A C$ & TR & GS & TS & $|B|$ \\
\hline$\overline{\mathrm{PU}}$ & & $.311^{(* *}$ & $.543^{(* *}$ & & & & & & \\
\hline$\overline{\text { PEoU }}$ & & 1 & $.312^{(* *}$ & & & & & & \\
\hline$\overline{\mathrm{SN}}$ & & & & & & & & & \\
\hline$\overline{T S E}$ & $.421^{(* \star}$ & $.383^{(\star *}$ & $.481^{(* *}$ & 1 & & & & & $\left..473^{(\star \star}\right)$ \\
\hline$\overline{A C}$ & $.285^{(* *}$ & $.303^{(\star *}$ & $323^{(* *}$ & $.211^{(\star *}$ & 1 & $.189(* \star)$ & $.162(* \star)$ & 0.06 & $\left..240^{(\star *}\right)$ \\
\hline TR & $.253^{(*)}$ & $.242^{(* \star}$ & $.243^{(* *}$ & $.311^{(* \star}$ & & & 0.04 & & $.279^{(\star \star}$ \\
\hline$\overline{G S}$ & $.292^{(* *}$ & $.328^{(* *}$ & $.3011^{(*)}$ & $.268^{(\star *}$ & & & 1 & & $\left..3844^{(\star \star}\right)$ \\
\hline TS & $.318^{(* *}$ & $.281\left({ }^{(*)}\right.$ & $.3322^{(*)}$ & $\left..373^{(* \star}\right)$ & & $.175^{(\star \star}$ & $.375^{(* *}$ & 1 & $\left..338^{(\star \star}\right)$ \\
\hline$\overline{B I}$ & $.603^{(* *}$ & $.462\left({ }^{(*)}\right.$ & $.545^{(* *}$ & & & & & & \\
\hline
\end{tabular}

Mahalanobis distance (D2) test and boxplots are used to test multivariate and univariate outliers, respectively. As shown in Table 10, the maximum value of D2 (23.112) is lower than the minimum cutoff limit of 27.653 and shows that there are no outliers in final set of 9 variables from total of 403 entries.

\begin{tabular}{|c|c|c|c|c|}
\hline & Std. Dev & Mean & Min. & Max \\
\hline $\begin{array}{l}\text { Predicted } \\
\text { Value }\end{array}$ & 38.68 & 177 & 70.46 & 304.26 \\
\hline $\begin{array}{l}\text { Std. } \\
\text { Predicted } \\
\text { Value } \\
\end{array}$ & 1 & 0 & -2.754 & 3.29 \\
\hline \begin{tabular}{|l|} 
Standard \\
Error of \\
Predicted \\
Value \\
\end{tabular} & 4.713 & 15.4 & 6.26 & 25.058 \\
\hline $\begin{array}{l}\text { Adjusted } \\
\text { Predicted } \\
\text { Value }\end{array}$ & 38.864 & 176.2 & 67.55 & 308.26 \\
\hline Residual & 94.441 & 0 & -204.26 & 223.08 \\
\hline $\begin{array}{l}\text { Std. } \\
\text { Residual }\end{array}$ & 0.987 & 0 & -2.135 & 2.332 \\
\hline \begin{tabular}{|l} 
Stud. \\
Residual \\
\end{tabular} & 1.002 & 0.004 & -2.154 & 2.405 \\
\hline $\begin{array}{l}\text { Deleted } \\
\text { Residual } \\
\end{array}$ & 97.341 & 0.805 & -207.95 & 237.24 \\
\hline $\begin{array}{l}\text { Stud. } \\
\text { Deleted } \\
\text { Residual } \\
\end{array}$ & 1.004 & 0.004 & -2.166 & 2.422 \\
\hline \begin{tabular}{|l|} 
Mahal. \\
Distance \\
\end{tabular} & 5.806 & 8.975 & 0.51 & 23.15 \\
\hline \begin{tabular}{|l} 
Cook's \\
Distance
\end{tabular} & 0.005 & 0.003 & $\overline{0}$ & 0.037 \\
\hline $\begin{array}{l}\text { Centered } \\
\text { Leverage }\end{array}$ & 0.016 & 0.025 & 0.001 & 0.066 \\
\hline
\end{tabular}

The normality of data was tested using the Shapiro-Wilk test and the Kolmogorov-Smirnov test. Table 11 signifies that the data was normal.

Table 11 - Test of Normality

\begin{tabular}{|l|l|l|l|l|l|l|}
\hline & \multicolumn{3}{|c|}{ Shapiro-Wilk } & \multicolumn{2}{|c|}{ Kolmogorov-Smirnov(a) } \\
\hline & Sig. & Df & Statistics & Sig. & Df & Statistics \\
\hline PU & 0 & 403 & 0.848 & 0 & 403 & 0.219 \\
\hline PEoU & 0 & 403 & 0.855 & 0 & 403 & 0.212 \\
\hline SN & 0 & 403 & 0.821 & 0 & 403 & 0.226 \\
\hline TSE & 0 & 403 & 0.856 & 0 & 403 & 0.202 \\
\hline AC & 0 & 403 & 0.869 & 0 & 403 & 0.221 \\
\hline TR & 0 & 403 & 0.858 & 0 & 403 & 0.255 \\
\hline GS & 0 & 403 & 0.887 & 0 & 403 & 0.199 \\
\hline TS & 0 & 403 & 0.868 & 0 & 403 & 0.237 \\
\hline BI & 0 & 403 & 0.821 & 0 & 403 & 0.239 \\
\hline
\end{tabular}

The Levene's test indicates the homogeneity in all constructs except Perceived Ease of Use. Table 12 shows the test of homogeneity of variance.
Table 12 - Test of Homogeneity of Variance

\begin{tabular}{|c|c|c|c|c|c|}
\hline Constructs & & \begin{tabular}{|l|} 
Levene's \\
Statistics
\end{tabular} & Df1 & Df2 & Sig. \\
\hline \multirow[t]{4}{*}{$\mathrm{PU}$} & BIM & 0.004 & 1 & 401 & 0.95 \\
\hline & $\overline{B o M}$ & 0.045 & 1 & 401 & 0.83 \\
\hline & BoM(df) & 0.045 & 1 & 401 & 0.83 \\
\hline & $\overline{B T M}$ & 0.031 & 1 & 401 & 0.86 \\
\hline \multirow[t]{4}{*}{ PEoU } & BIM & 4.737 & 1 & 401 & 0.03 \\
\hline & BoM & 1.124 & 1 & 401 & 0.29 \\
\hline & BoM(df) & 1.124 & 1 & 444.2 & 0.29 \\
\hline & $\overline{B T M}$ & 2.157 & 1 & 401 & 0.04 \\
\hline \multirow[t]{4}{*}{$\mathrm{SN}$} & BIM & 1.033 & 1 & 401 & 0.31 \\
\hline & $\overline{B o M}$ & 0.538 & 1 & 401 & 0.46 \\
\hline & BoM(df) & 0.538 & 1 & 401 & 0.46 \\
\hline & $\overline{B T M}$ & 1.101 & 1 & 401 & 0.3 \\
\hline \multirow[t]{4}{*}{ TSE } & BIM & 0 & 1 & 401 & 0.99 \\
\hline & $\overline{B o M}$ & 0.014 & 1 & 401 & 0.91 \\
\hline & BoM(df) & 0.014 & 1 & 398.8 & 0.91 \\
\hline & BTM & 0 & 1 & 401 & 0.99 \\
\hline \multirow[t]{4}{*}{$A C$} & BIM & 0.084 & 1 & 401 & 0.77 \\
\hline & BoM & 0.278 & 1 & 401 & 0.6 \\
\hline & BoM(df) & 0.278 & 1 & 401 & 0.6 \\
\hline & $\overline{\text { BTM }}$ & 0.132 & 1 & 401 & 0.72 \\
\hline \multirow[t]{4}{*}{ TR } & BIM & 1.063 & 1 & 401 & 0.3 \\
\hline & BoM & 0.29 & 1 & 401 & 0.59 \\
\hline & BoM(df) & 0.29 & 1 & 400.3 & 0.59 \\
\hline & $\overline{\text { BTM }}$ & 0.867 & 1 & 401 & 0.35 \\
\hline \multirow[t]{4}{*}{ GS } & BIM & 0.043 & 1 & 401 & 0.84 \\
\hline & BoM & 0.236 & 1 & 401 & 0.63 \\
\hline & BoM(df) & 0.236 & 1 & 396 & 0.63 \\
\hline & BTM & 0.074 & 1 & 401 & 0.79 \\
\hline \multirow[t]{4}{*}{ TS } & BIM & 0.194 & 1 & 401 & 0.66 \\
\hline & BoM & 0.184 & 1 & 401 & 0.67 \\
\hline & BoM(df) & 0.184 & 1 & 399.8 & 0.67 \\
\hline & BTM & 0.245 & 1 & 401 & 0.62 \\
\hline \multirow[t]{4}{*}{$\mathrm{BI}$} & $\mathrm{BIM}$ & 0.742 & 1 & 401 & 0.39 \\
\hline & BoM & 0.296 & 1 & 401 & 0.59 \\
\hline & BoM(df) & 0.296 & 1 & 401 & 0.59 \\
\hline & $\overline{\text { BTM }}$ & 0.686 & 1 & 401 & 0.41 \\
\hline
\end{tabular}

The results from the above table clarify that data is ready to apply in Structured Equation Modeling to test the hypothesis and verify the framework.

\section{STRUCTURAL EQUATION MODELING (SEM) ANALYSIS}

The relationship between constructs was tested using twostep SEM, and a framework was developed. Confirmatory Factor Analysis (CFA) was used to validate the relationship between the measurement items using AMOS, and a structured model was used to study the relationship between the constructs.

Confirmatory factor analysis was conducted, which confirms the validity and reliability of the measurement model. The first step is to check the goodness of fit (GOF). The GOF indices used parsimonious fit indices, incremental fit indices, and absolute fit indices to prove the fitness of constructs in the final framework. Table 13 shows a summary of the results derived from the initial CFA.

Note: $\chi 2=$ Chi-square; $\mathrm{df}=$ degree of freedom; GFI = Goodness of fit index; RMSEA = Root mean square error of approximation; NFI = Normated fit index; CFI = Comparative fit index; AGFI - Adjusted goodness of fit index

\section{Published By:}

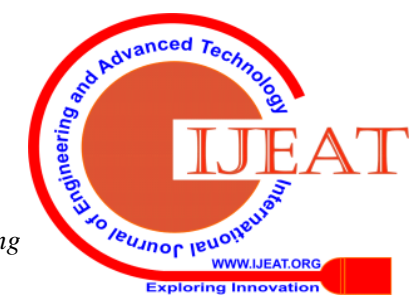


Table 13 - Goodness of fit statistics for the Initial CFA

\begin{tabular}{|c|c|c|c|c|c|}
\hline & & Parsimony Fit Indices & Incremental Fit Indices & Absolute & Fitlindices \\
\hline & $x^{2}$ & \begin{tabular}{|l|l|l|} 
Df & AGFI \\
\end{tabular} & \begin{tabular}{|l|l|l|}
$N F I$ & $C F I$ \\
\end{tabular} & X2ldf & \begin{tabular}{|l|l}
$G F \mid$ & $F$
\end{tabular} \\
\hline Citteria & & 20.90 & $\geq 0.90 \geq 0.90$ & $1<\times 2 \mid d k 3$ & $\geq 0.90<0.05$ \\
\hline Obtanned & 939.31 & $462 \mid 0.899$ & 0.940 .948 & 2.272 & 0.9 \\
\hline
\end{tabular}

Chi-square statistics indicates that data to the model was not significant and therefore model to be rejected, and it is, therefore, important to switch the analysis to other fit indices like NFI = Normated fit index $; \mathbf{C F I}=$ Comparative fit index; RMSEA $=$ Root mean square error of approximation, GFI = Goodness of fit index; AGFI Adjusted goodness of fit index. The Chi-square test is mainly dependent on sample size, and it applies to data that doesn't follow the normality.

Results from Table 11 and Table 13 depict that the numbers are not in sync with each other, and therefore the model needs to be refined.

The cutoff value for squared multiple correlations and factor loading is 0.5 and 0.7, respectively (Byrne, 2001). The standard residual value shall lie between -2.58 to 2.58 (Hair et al. 2006). (Hair et al., 2006) opined that limit of modification indices which represents high value of covariance and regression weight also needs to be checked. When the results from data are tested and validated against the output of the CFA applied to the older model. It was observed that factor loading was passed for all the measurement items but "Flexible," "Comfort learning from peers," "Continuity" and "Influence of Media" got high degree of residual variance and therefore they were dropped from the list. Once these items were removed from the list, according to (Hair et al., 2006; Kline, 2005) CFA was rerun.

Table 14 clearly shows the goodness of fit indices, concerning every criterion, improved from the revised model

Table 14 - Goodness of Fit Statistics of revised CFA Model

\begin{tabular}{|c|c|c|c|c|c|c|c|c|}
\hline & & & Darsimony Fiti nndices & Increme & ntad Fit Indices & Alssoll & $\| e^{\prime}|t|$ & ndices \\
\hline & 12 & $\mathrm{Dt}^{\mathrm{f}}$ & AGEF & NEF & CFI & 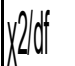 & GF & F \\
\hline Cuilenild & & & $\geq 0.90$ & $\geq 0.00$ & $\geq 0.90$ & & 20.00 & $<0,05$ \\
\hline bhtanned & 821,15 & 546 & 0.095 & 0.923 & 0.987 & 1.834 & 0.91 & 0.015 \\
\hline
\end{tabular}

Once the goodness of fit indices was done, the discriminant, nomological and convergent validity was done to make sure, new constructs are valid to be used to form a model.

Table 15 shows the results of convergent validity, which points out that the revised CFA model clears of the minimum cut off, and it is better than the previous one.
Table 15 - Convergent Validity

\begin{tabular}{|c|c|c|c|c|}
\hline Construct & Item & \begin{tabular}{|l|} 
Average \\
Variance \\
Extracted
\end{tabular} & \begin{tabular}{|l|} 
Critical \\
Ratio \\
(T-value)
\end{tabular} & \begin{tabular}{|l|} 
Standardized \\
Factor Loading
\end{tabular} \\
\hline \multirow{5}{*}{ PU } & Easier Transaction & \multirow[t]{5}{*}{0.772} & 21.423 & 0.875 \\
\hline & Improved Effectiveness & & 22.463 & 0.869 \\
\hline & Improved Productivity & & $\ldots \ldots \ldots \ldots$ & 0.845 \\
\hline & Saves time & & 22.391 & 0.813 \\
\hline & Quick Transaction & & 21.946 & 0.869 \\
\hline \multirow{5}{*}{ PEOU } & Skill Improvement & \multirow[t]{5}{*}{0.763} & 25.712 & 0.863 \\
\hline & Clear & & 24.839 & 0.801 \\
\hline & Easy to Learn & & 23.145 & 0.823 \\
\hline & Accessibility & & 21.429 & 0.893 \\
\hline & Overall Rating & & & 0.914 \\
\hline \multirow{7}{*}{ SN } & Teaching others & \multirow[t]{7}{*}{0.726} & 19.518 & 0.821 \\
\hline & Influence of friends & & 20.732 & 0.862 \\
\hline & Societal Influence & & 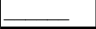 & 0.812 \\
\hline & Influence of family & & 21.312 & 0.845 \\
\hline & Sharing Experience & & 20.874 & 0.832 \\
\hline & Peer Influence & & 20.563 & 0.841 \\
\hline & Overall Rating & & 20.295 & 0.892 \\
\hline \multirow{4}{*}{ TSE } & Comfort learning on my own & \multirow[t]{4}{*}{0.665} & 17.873 & 0.792 \\
\hline & Comfort with reference manual & & 19.151 & 0.854 \\
\hline & Comfort in using first time & & 18.238 & 0.813 \\
\hline & Overall Comfort in Usage & & & 0.819 \\
\hline \multirow{2}{*}{ AC } & Ease and variety of access & \multirow[t]{2}{*}{0.751} & & 0.894 \\
\hline & Unrestricted access & & 10.263 & 0.832 \\
\hline \multirow{2}{*}{ Trust } & Security of Money & \multirow[b]{2}{*}{0.789} & 9.652 & 0.883 \\
\hline & Fraud Free & & & 0.873 \\
\hline \multirow{2}{*}{ GS } & Technology Promotion & \multirow[t]{2}{*}{0.878} & 13.547 & 0.903 \\
\hline & Government Facilitation & & - & 0.893 \\
\hline \multirow{2}{*}{ TSE } & Network Availability & \multirow[t]{2}{*}{0.901} & 13.672 & 0.911 \\
\hline & Customer Care & & & 0.934 \\
\hline \multirow{4}{*}{ BI } & Recommendation to Peers & \multirow[t]{4}{*}{0.725} & 24.873 & 0.873 \\
\hline & Often and Diverge Usage & & $=^{*}$ & 0.893 \\
\hline & Future Usage & & 23.174 & 0.899 \\
\hline & Consistency & & 23.834 & 0.903 \\
\hline
\end{tabular}

* Regression Weight 1

Tables 16 and 17 shows strong and significant discriminant validity for the constructs

Table 16 - Inter Construct Correlations

\begin{tabular}{|l|r|r|r|r|l|l|l|l|r|}
\hline & PU & PEOU & SN & TSE & AC & TR & GS & TS & BI \\
\hline PU & 1 & & & & & & & & 0.63 \\
\hline PEOU & 0.34 & 1 & & & & & & & 0.42 \\
\hline SN & 0.58 & 0.342 & 1 & 0.28 & 0.32 & 0.24 & 0.29 & 0.36 & 0.56 \\
\hline TSE & 0.44 & 0.431 & & 1 & & & & & 0.51 \\
\hline AC & 0.3 & 0.314 & & 0.21 & 1 & & & 0.06 & 0.25 \\
\hline TR & 0.28 & 0.298 & & 0.35 & 0.21 & 1 & & 0.11 & 0.29 \\
\hline GS & 0.3 & 0.351 & & 0.29 & 0.16 & 0.07 & 1 & 0.41 & 0.4 \\
\hline TS & 0.57 & 0.325 & & 0.39 & & & & 1 & 0.37 \\
\hline BI & & & & & & & & & 1 \\
\hline
\end{tabular}

Table 17 - Discriminant Validity

\begin{tabular}{|l|r|r|r|r|r|l|l|l|l|}
\hline & PU & PEoU & SN & TSE & AC & TR & GS & TS & BI \\
\hline PU & $\mathbf{0 . 7 2}$ & & & & & & & & 0.38 \\
\hline PEoU & 0.11 & $\mathbf{0 . 7 8 8}$ & & & & & & & 0.23 \\
\hline SN & 0.34 & 0.135 & $\mathbf{0 . 7 4}$ & 0.11 & 0.14 & 0.07 & 0.05 & 0.11 & 0.31 \\
\hline TSE & 0.2 & 0.183 & & $\mathbf{0 . 6 7}$ & & & & & 0.24 \\
\hline AC & 0.08 & 0.121 & & 0.06 & $\mathbf{0 . 7 9}$ & & & 0.01 & 0.06 \\
\hline TR & 0.06 & 0.099 & & 0.15 & 0.08 & $\mathbf{0 . 7 5}$ & 0.05 & & 0.07 \\
\hline GS & 0.08 & 0.142 & & 0.1 & 0.03 & 0.01 & $\mathbf{0 . 8 3}$ & 0.2 & 0.16 \\
\hline TS & 0.35 & 0.101 & & 0.18 & & & & $\mathbf{0 . 9}$ & 0.13 \\
\hline BI & & & & & & & & & $\mathbf{0 . 7 6}$ \\
\hline
\end{tabular}

Note: Diagonal values are AVE, and off-diagonal are inter-construct squared correlations

In the end, a Nomological validity test will be done where the correlation between the measurement model constructs will be checked. Table 18 and Table 19 shows the results of nomological validity which depicts that there is some positive relationship between government support and technical support, but the level of significance is very low similarly trust, and government support shows low level of significance. Apart from these two other values are consistent and supported nomological validity. 
Table 18 - AMOS output - Covariances: (Group number 1 - Default model)

\begin{tabular}{|c|c|c|c|c|}
\hline $\mathrm{P}$ & C.R & S.E & Estimate & Relationship between variables \\
\hline 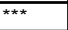 & 6.459 & 0.183 & 1.214 & TS $<-->$ TSE \\
\hline 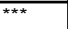 & 3.625 & 0.156 & 0.527 & $A C<-->T S E$ \\
\hline 0.209 & 1.325 & 0.19 & 0.242 & $\overline{A C<-->T S}$ \\
\hline 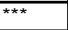 & 5.125 & 0.152 & 0.883 & TR<-->TSE \\
\hline 0.002 & 3.042 & 0.145 & 0.515 & TR<-->TS \\
\hline 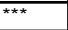 & 3.127 & 0.162 & 0.562 & TR<-->AC \\
\hline 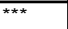 & 4.623 & 0.131 & 0.762 & GS<-->TSE \\
\hline 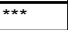 & 6.568 & 0.213 & 1.114 & GS $<-->T S$ \\
\hline 0.003 & 3.124 & 0.182 & 0.624 & GS $<-->A C$ \\
\hline 0.132 & 1.423 & 0.145 & 0.324 & $\overline{G S<-->T R}$ \\
\hline 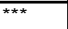 & 7.678 & 0.165 & 1.423 & $\mathrm{SN}<-->\mathrm{TSE}$ \\
\hline 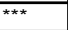 & 6.125 & 0.156 & 1.132 & $\mathrm{SN}<-->\mathrm{TS}$ \\
\hline 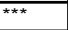 & 5.568 & 0.176 & 0.924 & $\mathrm{SN}<-->A C$ \\
\hline 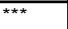 & 4.021 & 0.141 & 0.634 & $\mathrm{SN}<-->\mathrm{TR}$ \\
\hline 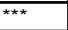 & 5.234 & 0.189 & 0.883 & $\mathrm{SN}<-->\mathrm{GS}$ \\
\hline 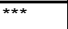 & 6.872 & 0.147 & 1.104 & $\overline{T S E<-->P E O U}$ \\
\hline 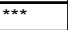 & 5.512 & 0.115 & 1.103 & TS<-->PEOU \\
\hline 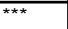 & 5.262 & 0.193 & 0.982 & AC<-->PEOU \\
\hline 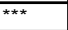 & 5.021 & 0.179 & 0.621 & TR<-->PEOU \\
\hline 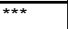 & 5.81 & 0.193 & 1.121 & $\overline{G S}<-->$ PEOU \\
\hline 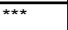 & 6.1 & 0.152 & 0.912 & SN<-->PEOU \\
\hline 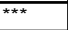 & 6.235 & 0.174 & 0.923 & PU<-->PEoU \\
\hline 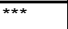 & 7.138 & 0.152 & 1.132 & TSE<-->PU \\
\hline 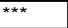 & 5.672 & 0.181 & 1.103 & $\overline{T S}<-->P U$ \\
\hline 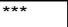 & 4.873 & 0.172 & 0.817 & $A C<-->P U$ \\
\hline 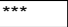 & 4.662 & 0.159 & 0.752 & TR<-->PU \\
\hline 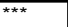 & 5.114 & 0.189 & 0.867 & GS $<-->P U$ \\
\hline 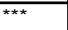 & 8.521 & 0.166 & 1.423 & SN<-->PU \\
\hline 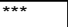 & 9.024 & 0.188 & 1.723 & $\mathrm{BK}<-->\mathrm{PU}$ \\
\hline 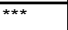 & 7.79 & 0.179 & 1.334 & Bl<-->PEOU \\
\hline 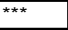 & 7.613 & 0.15 & 1.253 & Bl<-->TSE \\
\hline 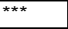 & 6.124 & 0.171 & 1.111 & Bl<-->TS \\
\hline 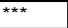 & 4.146 & 0.174 & 0.752 & $B \mathrm{BK}-->\mathrm{AC}$ \\
\hline 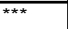 & 4.538 & 0.182 & 0.762 & $\overline{B K}<-->\mathrm{TR}$ \\
\hline 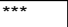 & 6.341 & 0.192 & 1.102 & $\mathrm{BK}<-->\mathrm{GS}$ \\
\hline 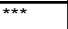 & 7.345 & 0.162 & 1.312 & $\overline{B l}<-->S N$ \\
\hline
\end{tabular}

Table 19 - AMOS output - Construct Correlations:

(Group number 1 - Default model)

\begin{tabular}{|c|c|}
\hline Estimate & Relationship between variables \\
\hline 0.415 & TS<-->TSE \\
\hline 0.236 & AC<-->TSE \\
\hline 0.15 & $A C<-->T S$ \\
\hline 0.352 & TR<-->TSE \\
\hline 0.193 & TR<-->TS \\
\hline 0.238 & TR<-->AC \\
\hline 0.323 & GS<-->TSE \\
\hline 0.434 & $\mathrm{GS}<-->\mathrm{TS}$ \\
\hline 0.203 & GS $<-->A C$ \\
\hline 0.123 & GS<-->TR \\
\hline 0.545 & $\mathrm{SN}<-->\mathrm{TSE}$ \\
\hline 0.312 & $\mathrm{SN}<-->\mathrm{TS}$ \\
\hline 0.234 & $\mathrm{SN}<-->A C$ \\
\hline 0.303 & $\mathrm{SN}<-->\mathrm{TR}$ \\
\hline 0.316 & $\mathrm{SN}<-->\mathrm{GS}$ \\
\hline 0.453 & TSE<-->PEoU \\
\hline 0.342 & TS<-->PEoU \\
\hline 0.343 & AC<-->PEoU \\
\hline 0.312 & TR<-->PEoU \\
\hline 0.373 & GS<-->PEoU \\
\hline 0.364 & $\mathrm{SN}<-->\mathrm{PEOU}$ \\
\hline 0.323 & PU<-->PEoU \\
\hline 0.473 & TSE<-->PU \\
\hline 0.364 & $\mathrm{TS}<-->\mathrm{PU}$ \\
\hline 0.317 & $A C<-->P U$ \\
\hline 0.304 & TR<-->PU \\
\hline 0.329 & GS<-->PU \\
\hline 0.621 & $\mathrm{SN}<-->\mathrm{PU}$ \\
\hline 0.62 & $\mathrm{BK}<-->\mathrm{PU}$ \\
\hline 0.504 & Bl<-->PEoU \\
\hline 0.524 & $\mathrm{BK}<-->\mathrm{TSE}$ \\
\hline 0.403 & $\mathrm{BK}<-->\mathrm{TS}$ \\
\hline 0.273 & $\mathrm{Bl}<-->\mathrm{AC}$ \\
\hline 0.302 & $\mathrm{BI}<-->\mathrm{TR}$ \\
\hline 0.423 & $\mathrm{BK}<-->\mathrm{GS}$ \\
\hline 0.534 & $\mathrm{Bl}<-->\mathrm{SN}$ \\
\hline
\end{tabular}

The constructs derived from the literature were divided into exogenous constructs and endogenous constructs. Exogenous constructs are government support, technology self-efficacy, technical support, subjective norm, trust, and accessibility. Whereas, perceived usefulness, perceived ease of use, and behavioral constructs are classified as endogenous variables.

Table 20 -Structural model fit measurement assessment

\begin{tabular}{|c|c|c|c|c|c|c|c|c|}
\hline & & & Parsimony Fit Indices & \multicolumn{2}{|c|}{ Incremental Fit Indices } & \multicolumn{3}{|c|}{ Absolute Fit Indices } \\
\hline & $x^{2}$ & $\overline{D f}$ & AGFI & $\mathrm{NFI}$ & $\mathrm{CFI}$ & $\mathrm{x}^{2 / \mathrm{df}}$ & $\mathrm{GFI}$ & $\mathrm{F}$ \\
\hline Criteria & & & $? 0.90$ & $? 0.90$ & $? 0.90$ & $\begin{array}{l}1< \\
\times 2 / d f<3\end{array}$ & $? 0.90$ & $<0.05$ \\
\hline Obtained & 868.9 & 534 & 0.901 & 0.913 & 0.959 & 1.795 & 0.91 & 0.048 \\
\hline
\end{tabular}

Note: $\chi \mathbf{2}=$ Chi-square; $\mathbf{d f}=$ degree of freedom; $\mathbf{G F I}=$ Goodness of fit index

RMSEA = Root mean square error of approximation; NFI = Normated fit index; CFI = Comparative fit index; AGFI - Adjusted goodness of fit index

Table 20 clearly shows that parameters of the hypothesized structural model are closed to the goodness of fit.

It has been seen earlier; four items dropped, and 33 items were used to construct the model again. Similarly, it is again important to undertake the test, and the covariance matrix was build using these coefficient parameter estimates. The cutoff limit for the consideration was a critical ratio higher than 1.96 with confidence level of $95 \%$.

Table 21 - Regression estimates of latent constructs

\begin{tabular}{|l|l|l|l|l|}
\hline Significance $(\mathrm{P})$ & C.R & S.E & Estimate & Relationships \\
\hline$\star \star \star$ & 6.425 & 0.072 & 0.413 & PEoU <-- TSE \\
\hline$\star \star \star$ & 4.152 & 0.063 & 0.213 & PEoU <-- AC \\
\hline 0.005 & 2.834 & 0.054 & 0.178 & PEoU <-- TR \\
\hline$\star \star \star$ & 7.314 & 0.063 & 0.486 & PU <-- SN \\
\hline 0.1 & 1.662 & 0.052 & 0.112 & PU <-- PEoU \\
\hline 0.002 & 3.124 & 0.058 & 0.193 & PU <--TSE \\
\hline 0.242 & 1.142 & 0.054 & 0.052 & PU <--GS \\
\hline 0.146 & 1.502 & 0.053 & 0.082 & PU <--TS \\
\hline$\star \star \star$ & 4.963 & 0.037 & 0.302 & $\mathrm{BI}<--$ SN \\
\hline$\star \star \star$ & 7.397 & 0.042 & 0.397 & $\mathrm{BI}<-$ PU \\
\hline$\star \star \star$ & 6.113 & 0.041 & 0.283 & $\mathrm{BI}<--$ PEoU \\
\hline
\end{tabular}

Note: CR - Critical Ratio; SE - Standard Error

Table 21 clearly shows that 9 out of 12 paths drawn between the variables show a critical ratio higher than 1.96 , with a confidence level of $95 \%$. The path significance indicates the perfect relationship between two variables and therefore included in final model.

The hypothesized paths between the perceived usefulness and perceived ease of use; perceived usefulness and government support; perceived usefulness and technical support indicated that their t-values did not exceed the cutoff point required for statistical significance. Thus, these paths were not statistically significant. Table 22 shows the hypotheses testing by taking standard regression weights $(\beta)$.

Table 22 - Hypotheses Testing

\begin{tabular}{|l|c|c|c|}
\hline S.No & $\beta$ & Supported & Relationship (Positive) \\
\hline 1. & 0.672 & Yes & $\mathrm{BI} \rightarrow \mathrm{AU}$ (Hypothesis) \\
\hline 2. & 0.087 & No & $\mathrm{TS} \rightarrow \mathrm{PU}$ \\
\hline 3. & 0.077 & No & GS $\rightarrow \mathrm{PU}$ \\
\hline 4. & 0.139 & Yes & TR $\rightarrow$ PEoU \\
\hline 5. & 0.373 & Yes & TSE $\rightarrow \mathrm{PEoU}$ \\
\hline 6. & 0.194 & Yes & TSE $\rightarrow \mathrm{PU}$ \\
\hline 7. & 0.279 & Yes & $\mathrm{SN} \rightarrow \mathrm{PEoU}$ \\
\hline 8. & 0.453 & Yes & $\mathrm{SN} \rightarrow \mathrm{PU}$ \\
\hline 9. & 0.288 & Yes & $\mathrm{PEoU} \rightarrow \mathrm{BI}($ Sub Hypothesis) \\
\hline 10. & 0.397 & Yes & $\mathrm{PU} \rightarrow \mathrm{BI}($ Sub-Hypothesis) \\
\hline
\end{tabular}

Three non-significant paths were removed, based on the above hypotheses testing. The structural model was respecified and resulted shown in table 23 and 24:

Published By:

1931 Blue Eyes Intelligence Engineering

\& Sciences Publication

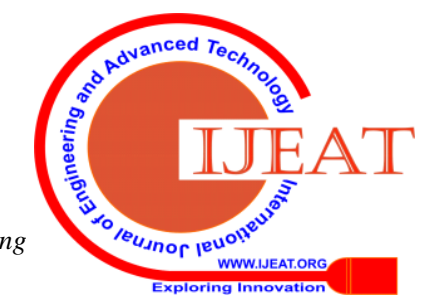


Table 23 Regression estimates of revised constructs after dropping insignificant paths

\begin{tabular}{|l|c|c|c|c|}
\hline S.No & $\beta$ & CR & Supported & Relationship (Positive) \\
\hline 1. & 0.24 & 4.128 & Yes $^{\star \star *}$ & $\mathrm{BI} \rightarrow \mathrm{AU}$ \\
\hline 2. & 0.139 & 2.851 & Yes $^{\star \star}$ & TR $\rightarrow$ PEoU \\
\hline 3. & 0.373 & 6.429 & Yes $^{\star \star \star}$ & TSE $\rightarrow$ PEoU \\
\hline 4. & 0.214 & 3.461 & Yes $^{\star \star \star}$ & TSE $\rightarrow$ PU \\
\hline 5. & 0.279 & 4.911 & Yes $^{\star \star *}$ & SN $\rightarrow$ PEoU \\
\hline 6. & 0.473 & 7.846 & Yes $^{\star \star *}$ & SN $\rightarrow$ PU \\
\hline 7. & 0.285 & 6.082 & Yes $^{\star \star *}$ & PEoU $\rightarrow \mathrm{BI}$ \\
\hline 8. & 0.399 & 7.291 & Yes $^{\star \star *}$ & PU $\rightarrow \mathrm{BI}$ \\
\hline
\end{tabular}

Table 24 Goodness of fit indices revised structural model

\begin{tabular}{|l|l|l|l|l|l|l|l|l|}
\hline & & & Parsimony Fit Indices & \multicolumn{3}{|c|}{ Incremental Fit Indices } & \multicolumn{3}{|c|}{ Absolute Fit Indices } \\
\hline & X2 & Df & AGFI & NFI & CFI & X2/df & GFI & RMSEA \\
\hline Criteria & & & $? 0.90$ & $? 0.90$ & $? 0.90$ & $\begin{array}{l}1< \\
X^{2} / d f 3\end{array}$ & $? 0.90$ & $<0.05$ \\
& & & & 0.935 & 0.975 & 1.571 & 0.94 & 0.039 \\
\hline Obtained & 578.27 & 368 & 0.933 & & & & \\
\hline
\end{tabular}

The new model was formed based on the above test results, and the same is shown below:

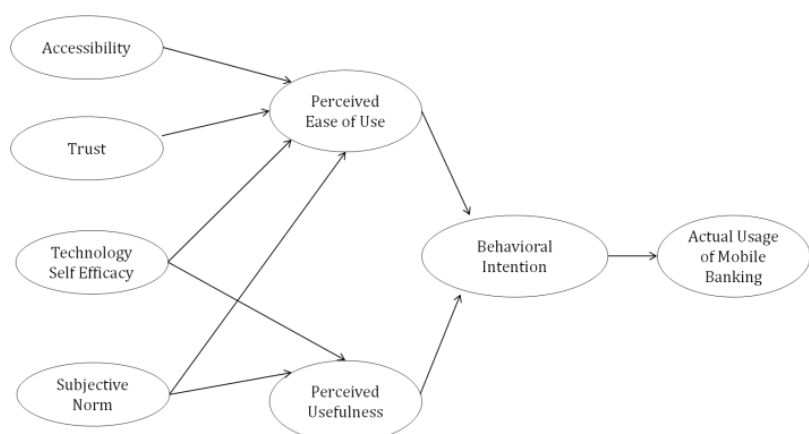

Figure 3 - Framework for mobile banking adoption to enhance financial inclusion in hilly areas of Champawat District

\section{DISCUSSION ON RESULTS AND CONCLUSION}

The framework developed by testing the hypothesised relationships between the variables indicates that behaviour intention incorporates a important and positive result on the usage of mobile banking for enhancing financial inclusion in Champawat, Uttrakhand udner MGNREGA. The framework additionally symbolises that perceived ease of use and perceived usefulness even have a positive impact on behaviour intention. Each of the key variables that are evidenced by earlier studies even have continuing to be associate degree integral section of the current analysis still. The results additionally mirror that users perception towards a technology primarily is answerable for their behaviour. Trust and Technology-self-efficacy additionally were integral elements in developing the perceptions of the respondents. Thus, it's essential to grasp that in future, the speed of diffusion is ordered on the pillars on trust, that are a slow method and language self-efficacy, which might build the users independent. The framework additionally indicates that accessibility to mobile banking also contend a necessary role in enhancing perception ease of use. The provision of mobile banking with all and sundry registered in MGNREGA and straightforward access to cash through business correspondent within the village makes a win-win state of affairs for the users. Technology self-efficacy additionally contend a significant role in creating developing the perception because it results in the event of confidence throughout the usage of mobile banking. The constant usage of mobile banking by the stakeholders helped the end-users to grasp the practicality and therefore the method of depositing and retreating cash from the system. Therefore, the framework offers a sturdy mechanism in addressing the problem of economic inclusion through technology diffusion in MGNREGA.

Future research can work on the critically of the constructs and therefore addressing the most critical constructs will help in forming effective strategy or policy to enhance mobile banking adoption in hilly areas and increasing financial inclusion.

\section{REFERENCES}

1. Alalwan, et al. (2017). Factors influencing adoption of mobile banking by Jordanian bank customers: Extending UTAUT2 with trust. International Journal of Information Management.

2. Hair, et al. (2006). Multivariate data analysis (Vol. 6). Upper Saddle River, NJ: Pearson Prentice Hall.

3. Kline, R. B. (2005). Principles and practice of structural equation modeling (2nd ed.). New York: Guilford.

4. Koenig-Lewis, et al. (2010), Predicting young consumers' take up mobile banking services, International Journal of Bank Marketing.

5. Koksal, (2016). The intentions of Lebanese consumers to adopt mobile banking. International Journal of Bank Marketing.

6. Mehta et al. (2019). Mobile Banking - An Answer to Financial Inclusion in Hilly Rural India, International Journal of Recent Technology and Engineering (IJRTE), Vol 8, Issue 4, November 2019, DOI:10.35940/ijrte.C5822.118419

\section{AUTHORS FROFILE}

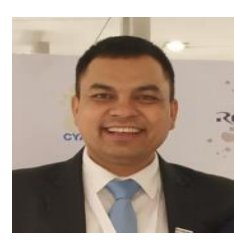

Anil Mehta - Research Scholar, University of Petroleum and Energy Studies, Dehradun, India

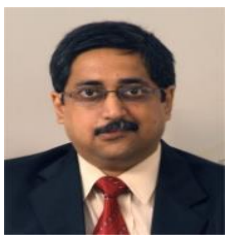

Dr. Deepankar Chakrabarti - Professor and Dean, University of Petroleum and Energy Studies, Dehradun, India

Dr. Rajeev Srivastava - Head of Department, Decision Science Department, University of Petroleum and Energy Studies, Dehradun, India
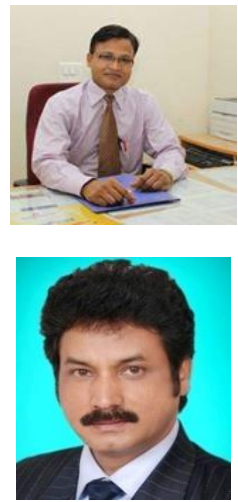

Dr. Ranjeet Mehta - Principal Director, PHD Chambers, New Delhi, India 